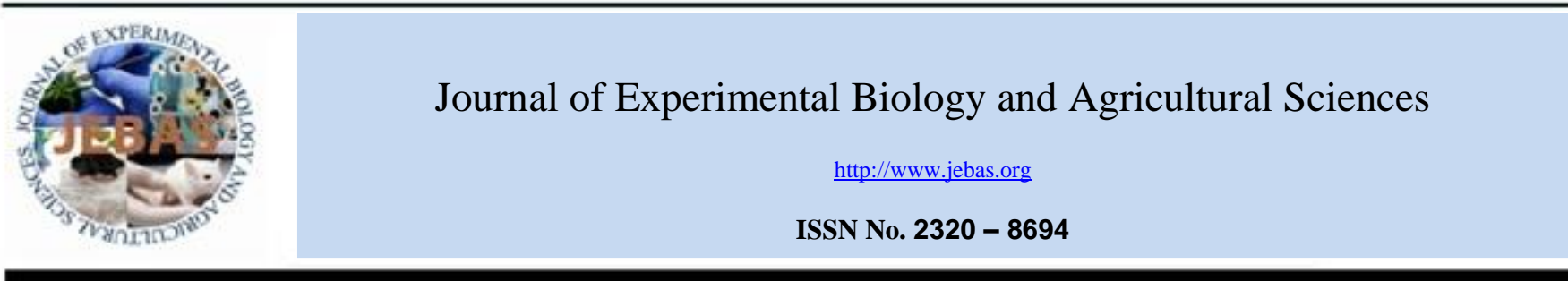

\title{
EFFECTS OF CULTIVATION SYSTEMS AND CULTIVARS ON GROWTH AND YIELD PERFORMANCE OF JAPANESE EGGPLANT IN THAILAND
}

\author{
Karistsapol Nooprom ${ }^{1}$, Niranee Bueraheng ${ }^{2}$ \\ ${ }^{1}$ Faculty of Agricultural Technology, Songkhla Rajabhat University, Muang, Songkhla 90000, Thailand \\ ${ }^{2}$ Faculty of Science Technology and Agriculture, Yala Rajabhat University, Muang, Yala, 95000, Thailand \\ Received - November 19, 2020; Revision - January 12, 2021; Accepted - February 24, 2021 \\ Available Online - February 27, 2021 \\ DOI: http://dx.doi.org/10.18006/2021.9(1).36.43
}

\section{KEYWORDS \\ Solanum melongena L. \\ Cultivation system \\ Eggplant cultivar \\ Organic farming}

\begin{abstract}
In the current study impacts of different cultivation systems and Japanese eggplant cultivars on their growth and yield were determined. Four Japanese eggplant cultivars viz., 'Fullness', 'Black Beauty', 'Wasedaimaru' and 'Israel' were grown under two systems of organic and conventional cultivations from 2 April to 16 July 2018 at the Faculty of Agricultural Technology, Songkhla Rajabhat University, Muang, Songkhla. The experimental arrangement used in this study was split-plots design (SPD) within a randomized complete block design (RCBD) with four replications. Results of the study indicated that 'Wasedaimaru' and 'Fullness' were suitable for growing under the organically managed production. 'Wasedaimaru' grown under an organic cultivation system had a lower yield per plant at 4,444.00g than grown under conventional chemical cultivation at $6,848.40 \mathrm{~g}$. The organic yield was not significantly different $(p \leq 0.05)$ from 'Fullness' grown under organic cultivation at 3,947.40g. 'Wasedaimaru' and 'Fullness' were identified as suitable cultivars for production under organic cultivation in Thailand with high yield.
\end{abstract}

* Corresponding author

E-mail: abhichard_n@hotmail.co.th (Karistsapol Nooprom)

Peer review under responsibility of Journal of Experimental Biology and Agricultural Sciences.

Production and Hosting by Horizon Publisher India [HPI] (http://www.horizonpublisherindia.in/).

All rights reserved.
All the articles published by Journal of Experimental Biology and Agricultural Sciences are licensed under a Creative Commons Attribution-NonCommercial 4.0 International License Based on a work at www.jebas.org.

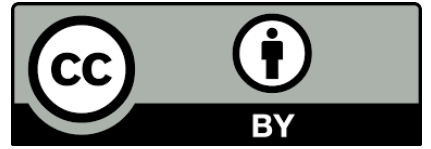




\section{Introduction}

Eggplant (Solanum melongena L.) is an economically important vegetable crop of tropical and subtropical zones (Niño-Mediana et al., 2017). It belongs to the Solanaceae or nightshade family (Decoteau, 2000). Suitable day temperatures for growth are 25$32^{\circ} \mathrm{C}$ while for the night it is $21-27^{\circ} \mathrm{C}$ (Abbas et al., 2011) Eggplant cultivars show a wide range of fruit shapes and colors (Luthria et al., 2010). In Thailand, eggplant cultivars are more spherical and display a range of colors. The fruit is small, with one cultivar resembling a chicken egg (Maynard, 2016). Japanese eggplant cultivars are economically important in many countries because the fruit is rich in antioxidants and is believed to reduce blood glucose levels (Fajriana et al., 2017). Thai eggplant farmers favor export to Japan which has high in demand (Sriwichai, 2004). However, Thai farmers are unable to satisfy Japanese eggplant market demand, with limited cultivation areas. Thailand's Department of Agricultural Extension (2021) reported that cultivated areas of Japanese eggplant were 70.36 hectares with an average total yield of 765.87 tons in 2020. Most of the cultivated areas are in the Northern Thailand including Chiang Mai, Lamphun, Phayao, Phetchabun, and Phitsanulok. Therefore, expanding cultivation to other regions of Thailand may be one choice to increase Japanese eggplant production for export.

Conventional agriculture is a farming system that is supported by synthetic chemicals in the production process (Campion et al., 2020). Increasing levels of pesticide resistance observed in recent years have been linked to the intensive use of chemicals and inorganic fertilizers. Conventional farming is expensive due to the high costs of chemicals (Ali et al., 2019) which negatively impact farmers, consumers, and the natural ecosystem (Benchasri et al., 2017). Organic agriculture is an alternative farming system involving the practice of crop production without chemicals or even growth hormones (Lima \&Vianello, 2011; Das et al., 2020). The role of organic farming is to create a balance between human health and ecological integrity (Yu et al., 2018; Clark, 2020). Vegetable crop yields grown under organic farming are generally $20 \%$ lower than crops grown under conventional chemicals systems (Orsini et al, 2016), and retail at a higher price by $20-30 \%$ (Nooprom, 2015).

One of the biggest challenges faced by organic farmers is the identification of locally adapted crop cultivars that can thrive under organic management conditions in the absence of chemical supports (Suja et al., 2016). Hence, the selection of potential crop cultivars is one of the most important decisions for organic farmers because locally adapted crop cultivars can thrive under organic management conditions (Nooprom, 2015). In this experiment, popular Japanese eggplant cultivars were grown under organic and conventional cultivation systems in Songkhla, Southern Thailand. Results can be used as a guideline for the growing of organic
Japanese eggplant in Songkhla province as a new source of Japanese eggplant production in Thailand.

\section{Materials and Methods}

This study was carried out in a research field at the Faculty of Agricultural Technology, Songkhla Rajabhat University, Muang, Songkhla, Thailand (Latitude $7^{\circ} 00^{\prime} 14.20^{\prime \prime} \mathrm{N}$, Longitude $100^{\circ} 30^{\prime}$ 1.75 " E, Altitude $56 \mathrm{~m}$ above sea level) from 2 April to 16 July 2018 using split-plots in a randomized complete block design with four replications. The main plots were subjected to two different cultivation systems as organic and chemical. The sub-plots were the four eggplant cultivars viz.,'Fullness', 'Black Beauty', 'Wasedaimaru' and 'Israel', with different fruit characteristics, sources, and original sources as shown in Table 1.

Organic and conventional experimental plots were spaced apart according to the requirements of the International Federation of Organic Agriculture Movements (2009). Before the experiment, sunn hemp (Crotalaria juncea) was sown and tilled to improve soil conditions and provide fixed nitrogen to the crop in organic cultivation systems (Benchasri \& Simla, 2017), while area without sunn hemp was used for the experiments sown under conventional cultivation systems. Japanese eggplant seeds were sown in nursery trays (104 holes). When the fourth true leaf had emerged, the seedlings were transferred into the field. The plot size was $1 \times 5 \mathrm{~m}$ and accommodated two rows of plants with six plants in each row. The plant, row, and edge spacing were $0.8 \times 0.9 \times 0.2 \mathrm{~m}$. The Japanese eggplant plants were watered two times a day in the morning and afternoon. Chemical fertilizers $(21 \mathrm{~N}-0 \mathrm{P}-0 \mathrm{~K}$ and $15 \mathrm{~N}-$ $6.5 \mathrm{P}-12.5 \mathrm{~K}$ ) were applied to the conventional cultivation system at a rate of 0.12 and $0.18 \mathrm{t} \mathrm{ha}^{-1}$, respectively. Cattle manure was applied to the organic cultivation system at the rate of $12.50 \mathrm{t} \mathrm{ha}^{-1}$. Both organic and conventional cultivation systems were weeded twice with a hand hoe at weeks 2 and 4 after transplanting. Chemical control of insects and diseases was practiced in the conventional cultivation system only, while biological control was used in the organic cultivation system.

Seedling survival rate at 30 days after transplanting (DAT) was recorded. Plant height was measured for ten random plants in the plot by the distance from the soil surface to the longest top leaf, while plant width was measured for ten random plants in the plot by the distance from the longest leaf on one side to the longest leaf on the opposite side. Stem diameter was measured for ten random plants in the plot by a digital caliper (Insize series 1108, U.S.A.). Number of days from growing to 50\% flowering and harvest were recorded in the experimental plots, while yield data were recorded from harvested eggplant plants in each plot. Soil samples in each plot were collected and analyzed for their properties at the Central Analytical Center, Faculty of Natural Resources, Prince of Songkla University, Hat Yai, Songkhla, Thailand. Data were analyzed using analysis of variance (ANOVA) and mean separation were done using Duncan's multiple range test (DMRT) at 0.05 probability level. 
Table 1 Fruit characteristics, sources and original sources of four cultivars of Japanese eggplant

\begin{tabular}{|cccccc|}
\hline Cultivar & Fruit Shape & Fruit Color & Calyx Color & Source & Original Source \\
& Globular & Dark purple & Green & Chiang Mai, Thailand & Thailand \\
\hline 'Fullness' & Teardrop & Dark purple & Green & Chiang Mai, Thailand & U.S.A. \\
\hline 'Wasedaimaru' & Teardrop & Dark purple & Purple & Bangkok, Thailand & Japan \\
\hline 'Israel' & Teardrop & Dark purple & Green & Phitsanulok, Thailand & Israel \\
\hline
\end{tabular}

\section{Results}

\subsection{Soil properties}

Soil properties of the study area soil are shown in Table 2. Before growing, soil under the conventional cultivation system had nitrogen $(\mathrm{N})$, available phosphorus $(\mathrm{P})$, potassium $(\mathrm{K})$, calcium (Ca), magnesium $(\mathrm{Mg})$, organic matter (O.M.) and potential of hydrogen ion $(\mathrm{pH})$ of $0.05 \%, 193.46 \mathrm{mg} / \mathrm{kg}, 100.16 \mathrm{mg} / \mathrm{kg}, 612.42$ $\mathrm{mg} / \mathrm{kg}, 75.63 \mathrm{mg} / \mathrm{kg}, 0.94 \%$ and 5.40 , respectively, while soil in the organic cultivation system had these properties at $0.06 \%$, $186.55 \mathrm{mg} / \mathrm{kg}, 112.12 \mathrm{mg} / \mathrm{kg}, 592.55 \mathrm{mg} / \mathrm{kg}, 66.98 \mathrm{mg} / \mathrm{kg}, 1.28 \%$ and 5.32, respectively. When the study was completed, soils under both organic and conventional cultivation systems were reanalyzed. Soil under the conventional cultivation system had increased nitrogen, available phosphorus, potassium, organic matter, and potential of hydrogen ion of $0.07 \%, 209.52 \mathrm{mg} / \mathrm{kg}$, $102.11 \mathrm{mg} / \mathrm{kg}, 1.03 \%$, and 5.79 , respectively, while calcium and magnesium decreased. In the organic cultivation system, soil had increased properties of all parameters compared with before growing.

\subsection{Growth responses}

Vegetative phase for Japanese eggplant grown under both organic and conventional cultivation systems was not significantly different $(p \leq 0.05)$ for seedling survival rates with values 98.42 and 98.95\%. 'Fullness', 'Wasedaimaru' and 'Israel' had the highest seedling survival rates with values of 98.95 to $100.00 \%$, followed by 'Black Beauty'. Interaction between different $(p \leq 0.05)$ cultivation systems and cultivars revealed no significant difference in seedling survival rates with values 95.80 to $100.00 \%$. Plants grown under the conventional cultivation system had higher plant height than those grown under the organic cultivation system with a mean value of $114.75 \mathrm{~cm}$. 'Israel' had the highest plant height with the value of $121.25 \mathrm{~cm}$, followed by 'Fullness', 'Wasedaimaru' and 'Black Beauty' with values of 98.50 to 104.75 . Interaction between different $(p \leq 0.05)$ cultivation systems and cultivars revealed that the greatest plant height was 'Israel'. 'Fullness' and 'Wasedaimaru' grown under the conventional cultivation system had values of 112.25 to $128.50 \mathrm{~cm}$ but they were not significantly different $(p \leq 0.05)$ from 'Fullness' grown under the organic cultivation system. 'Black Beauty' and 'Wasedaimaru' grown under the organic cultivation system had relatively low plant height. Japanese eggplant grown under the conventional cultivation system had higher plant width than those grown under the organic cultivation system with a mean value of $115.68 \mathrm{~cm}$. 'Israel' and 'Fullness' had high plant width with values of 110.37 to $117.75 \mathrm{~cm}$, with low plant width recorded by 'Black Beauty' and 'Wasedaimaru' with values of 83.75 to $92.37 \mathrm{~cm}$. Interaction between different cultivation systems and Japanese eggplant cultivars revealed that 'Israel' and 'Fullness' grown under the conventional cultivation system had a high plant width with values of 131.00 to $138.25 \mathrm{~cm}$, followed by 'Israel', 'Fullness' and 'Black Beauty' grown under the organic cultivation system, while 'Wasedaimaru' grown under the organic cultivation system had low plant width of $74.00 \mathrm{~cm}$. Japanese eggplant grown under both organic and conventional cultivation systems was not significantly different in stem diameter with values of 1.52 to $1.63 \mathrm{~cm}$. 'Fullness' 'Black Beauty' and 'Israel' had high stem diameter with values of 1.56 to $1.71 \mathrm{~cm}$, while 'Wasedaimaru' had low stem diameter of $1.36 \mathrm{~cm}$. Interaction between different cultivation systems and cultivars revealed that 'Fullness', 'Black Beauty' and 'Israel' grown under the conventional cultivation systems had high stem width with values of 1.62 to $1.77 \mathrm{~cm}$, which was not significantly different $(p \leq 0.05)$ from those grown under the organic cultivation system, while 'Wasedaimaru' grown under both organic and conventional cultivation systems had low stem width (Table 3).

The reproductive phase of Japanese eggplants grown under the conventional cultivation system had an early time to $50 \%$ flowering and harvest with values of 39.87 DAT and 58.75 DAT compared with those grown under the organic cultivation system with values of 43.43 DAT and 64.00 DAT. Times to $50 \%$ flowering and harvest of 'Fullness' were the earliest at 31.25 DAT and 57.00 DAT, respectively, followed by 'Wasedaimaru' and 'Black Beauty'. 'Israel' had the latest times to 50\% flowering and harvest with values of 54.87 DAT and 64.50 DAT. Interaction between different cultivation systems and cultivars revealed that 'Fullness' grown under both organic and conventional cultivation systems had early times to $50 \%$ flowering and harvest, with values of 30.50 to 32.00 DAT and 55.00 to 59.00 DAT, respectively and not significantly different $(p \leq 0.05)$ from "Wasedaimaru" grown 
Table 2 Soil properties in the experimental plots for the organic and conventional cultivation systems

\begin{tabular}{|ccccc|}
\hline \multirow{2}{*}{ Soil Property } & \multicolumn{2}{c}{ Organic Cultivation System } & \multicolumn{2}{c|}{ Conventional Cultivation System } \\
& Before Growing & After Growing & Before Growing & After Growing \\
\hline $\mathrm{N}(\%)$ & 0.06 & 0.08 & 0.05 & 0.07 \\
\hline Available P $(\mathrm{mg} / \mathrm{kg})$ & 186.55 & 216.31 & 193.46 & 209.52 \\
\hline $\mathrm{K}(\mathrm{mg} / \mathrm{kg})$ & 112.12 & 237.25 & 100.16 & 512.11 \\
\hline $\mathrm{Ca}(\mathrm{mg} / \mathrm{kg})$ & 592.55 & 769.88 & 75.63 & 32.68 \\
\hline $\mathrm{Mg}(\mathrm{mg} / \mathrm{kg})$ & 66.98 & 94.12 & 0.94 & 1.03 \\
\hline O.M. $(\%)$ & 1.28 & 1.76 & 5.40 & 5.79 \\
\hline $\mathrm{pH}$ & 5.32 & 5.51 & & 512.34 \\
\hline
\end{tabular}

Note: Soil samples were analyzed at the Central Analytical Center, Faculty of Natural Resources, Prince of Songkhla University, Songkhla Province, Thailand.

Table 3 Seedling survival rate, plant height, plant width, stem diameter, time to 50\% flowering and time to 50\% harvest of different Japanese eggplant cultivars under diverse cultivation systems

\begin{tabular}{|c|c|c|c|c|c|}
\hline \multirow{2}{*}{ Cultivation System } & \multicolumn{4}{|c|}{ Cultivar } & \multirow{2}{*}{ Mean } \\
\hline & 'Fullness' & 'Black Beauty' & 'Wasedaimaru' & 'Israel' & \\
\hline \multicolumn{6}{|l|}{ Seedling Survival Rate (\%) } \\
\hline Organic Cultivation & 97.90 & 95.80 & 100.00 & 100.00 & 98.42 \\
\hline Conventional Cultivation & 100.00 & 95.80 & 100.00 & 100.00 & 98.95 \\
\hline Mean & $98.95^{\mathrm{A}}$ & $95.80^{\mathrm{B}}$ & $100.00^{\mathrm{A}}$ & $100.00^{\mathrm{A}}$ & \\
\hline \multicolumn{6}{|l|}{ Plant Height $(\mathrm{cm})$} \\
\hline Organic Cultivation & $96.50^{\text {cd }}$ & $91.75^{\mathrm{d}}$ & $94.50^{d}$ & $114.00^{\mathrm{ab}}$ & $99.18^{\mathrm{B}}$ \\
\hline Conventional Cultivation & $113.00^{\text {abc }}$ & $105.25^{\mathrm{bcd}}$ & $112.25^{\mathrm{abc}}$ & $128.50^{\mathrm{a}}$ & $114.75^{\mathrm{A}}$ \\
\hline Mean & $104.75^{\mathrm{B}}$ & $98.50^{\mathrm{B}}$ & $103.37^{\mathrm{B}}$ & $121.25^{\mathrm{A}}$ & \\
\hline \multicolumn{6}{|l|}{ Plant Width (cm) } \\
\hline Organic Cultivation & $89.75^{\mathrm{bc}}$ & $84.75^{\mathrm{bc}}$ & $74.00^{\mathrm{c}}$ & $97.25^{\mathrm{b}}$ & $86.43^{\mathrm{B}}$ \\
\hline Conventional Cultivation & $131.00^{\mathrm{a}}$ & $100.00^{\mathrm{b}}$ & $93.50^{\mathrm{b}}$ & $138.25^{\mathrm{a}}$ & $115.68^{\mathrm{A}}$ \\
\hline Mean & $110.37^{\mathrm{A}}$ & $92.37^{\mathrm{B}}$ & $83.75^{\mathrm{B}}$ & $117.75^{\mathrm{A}}$ & \\
\hline \multicolumn{6}{|l|}{ Stem Diameter $(\mathrm{cm})$} \\
\hline Organic Cultivation & $1.64^{\mathrm{ab}}$ & $1.61^{\mathrm{ab}}$ & $1.35^{\mathrm{c}}$ & $1.50^{\mathrm{bc}}$ & 1.52 \\
\hline Conventional Cultivation & $1.77^{\mathrm{a}}$ & $1.75^{\mathrm{a}}$ & $1.37^{\mathrm{C}}$ & $1.62^{\mathrm{ab}}$ & 1.63 \\
\hline Mean & $1.71^{\mathrm{A}}$ & $1.68^{\mathrm{A}}$ & $1.36^{\mathrm{B}}$ & $1.56^{\mathrm{A}}$ & \\
\hline \multicolumn{6}{|l|}{ Time to $50 \%$ Flowering (DAT) } \\
\hline Organic Cultivation & $32.00^{f}$ & $49.00^{\mathrm{c}}$ & $35.25^{\mathrm{e}}$ & $57.50^{\mathrm{a}}$ & $43.43^{\mathrm{A}}$ \\
\hline Conventional Cultivation & $30.50^{f}$ & $45.50^{\mathrm{d}}$ & $31.25^{\mathrm{f}}$ & $52.25^{\mathrm{b}}$ & $39.87^{\mathrm{B}}$ \\
\hline Mean & $31.25^{\mathrm{D}}$ & $47.25^{\mathrm{B}}$ & $33.25^{\mathrm{C}}$ & $54.87^{\mathrm{A}}$ & \\
\hline \multicolumn{6}{|l|}{ Time to $50 \%$ Harvest (DAT) } \\
\hline Organic Cultivation & $59.00^{\text {cd }}$ & $65.00^{\mathrm{ab}}$ & $64.00^{\mathrm{ab}}$ & $68.00^{\mathrm{a}}$ & $64.00^{A}$ \\
\hline Conventional Cultivation & $55.00^{d}$ & $61.00^{\mathrm{bc}}$ & $58.00^{\mathrm{cd}}$ & $61.00^{\mathrm{bc}}$ & $58.75^{\mathrm{B}}$ \\
\hline Mean & $57.00^{\mathrm{C}}$ & $63.00^{\mathrm{AB}}$ & $61.00^{\mathrm{B}}$ & $64.50^{\mathrm{A}}$ & \\
\hline
\end{tabular}

DAT = Days after transplanting; Values sharing the same superscript letters are not significantly different $(p \leq 0.05)$ by Duncan's multiple range test 
Table 4 Fruit diameter, fruit length,fruit weight, fruit number per plant and yield per plant of different Japanese eggplant cultivars under diverse cultivation systems

\begin{tabular}{|c|c|c|c|c|c|}
\hline \multirow{2}{*}{ Cultivation System } & \multicolumn{4}{|c|}{ Cultivar } & \multirow{2}{*}{ Mean } \\
\hline & 'Fullness' & 'Black Beauty' & 'Wasedaimaru' & 'Israel' & \\
\hline \multicolumn{6}{|l|}{ Fruit Diameter $(\mathrm{cm})$} \\
\hline Organic Cultivation & $9.90^{\mathrm{a}}$ & $8.42^{\mathrm{bc}}$ & $8.67^{\mathrm{bc}}$ & $8.00^{\mathrm{c}}$ & 8.75 \\
\hline Conventional Cultivation & $10.30^{\mathrm{a}}$ & $8.54^{\mathrm{bc}}$ & $9.05^{b}$ & $8.05^{\mathrm{c}}$ & 8.98 \\
\hline Mean & $10.10^{A}$ & $8.48^{\mathrm{BC}}$ & $8.86^{\mathrm{B}}$ & $8.02^{\mathrm{C}}$ & \\
\hline \multicolumn{6}{|l|}{ Fruit Length $(\mathrm{cm})$} \\
\hline Organic Cultivation & $11.10^{\mathrm{b}}$ & $9.96^{\mathrm{b}}$ & $10.25^{\mathrm{b}}$ & $13.05^{\mathrm{a}}$ & 11.09 \\
\hline Conventional Cultivation & $11.44^{b}$ & $10.31^{b}$ & $10.95^{\mathrm{b}}$ & $13.81^{\mathrm{a}}$ & 11.63 \\
\hline Mean & $11.27^{\mathrm{B}}$ & $10.14^{\mathrm{C}}$ & $10.60^{\mathrm{BC}}$ & $13.43^{\mathrm{A}}$ & \\
\hline \multicolumn{6}{|l|}{ Fruit Weight (g) } \\
\hline Organic Cultivation & $292.88^{\mathrm{a}}$ & $228.00^{\mathrm{bc}}$ & $235.25^{\mathrm{bc}}$ & $195.65^{\mathrm{c}}$ & 237.94 \\
\hline Conventional Cultivation & $325.98^{\mathrm{a}}$ & $233.91^{\mathrm{bc}}$ & $280.93^{\mathrm{ab}}$ & $214.13^{\mathrm{c}}$ & 263.74 \\
\hline Mean & $309.43^{\mathrm{A}}$ & $230.96^{\mathrm{BC}}$ & $258.09^{\mathrm{B}}$ & $204.89^{C}$ & \\
\hline \multicolumn{6}{|l|}{ Fruit Number per Plant } \\
\hline Organic Cultivation & $13.50^{\mathrm{c}}$ & $14.25^{\mathrm{c}}$ & $19.00^{b}$ & $12.75^{\mathrm{c}}$ & $14.87^{\mathrm{B}}$ \\
\hline Conventional Cultivation & $14.25^{\mathrm{c}}$ & $15.25^{\mathrm{c}}$ & $24.25^{\mathrm{a}}$ & $15.00^{\mathrm{c}}$ & $17.18^{\mathrm{A}}$ \\
\hline Mean & $13.87^{\mathrm{B}}$ & $14.75^{\mathrm{B}}$ & $21.62^{\mathrm{A}}$ & $13.87^{\mathrm{B}}$ & \\
\hline \multicolumn{6}{|l|}{ Yield per Plant (g) } \\
\hline Organic Cultivation & $3947.40^{\mathrm{bc}}$ & $3290.00^{\mathrm{cd}}$ & $4444.00^{\mathrm{bc}}$ & $2496.90^{\mathrm{d}}$ & $3544.60^{B}$ \\
\hline Conventional Cultivation & $4649.10^{\mathrm{b}}$ & $3564.00^{\mathrm{bcd}}$ & $6848.40^{\mathrm{a}}$ & $3231.10^{\text {cd }}$ & $4573.10^{\mathrm{A}}$ \\
\hline Mean & $4298.20^{\mathrm{B}}$ & $3427.00^{\mathrm{C}}$ & $5646.20^{\mathrm{A}}$ & $2864.00^{\mathrm{C}}$ & \\
\hline
\end{tabular}

Values sharing the same superscript letters are not significantly different $(p \leq 0.05)$ by Duncan's multiple range test

under the conventional cultivation system. The latest time to $50 \%$ flowering was 'Israel' grown under the organic cultivation system with a value of 57.50 DAT, corresponding to $50 \%$ harvest of 68.00 DAT (Table 3).

\subsection{Yield responses}

Japanese eggplants grown under both organic and conventional cultivation systems were not significantly different in fruit diameter, fruit length, and fruit weight as shown in Table 4. 'Fullness' had the highest fruit diameter and weight with values of $10.10 \mathrm{~cm}$ and $309.43 \mathrm{~g}$, respectively, while 'Israel' had the highest fruit length with a value of $13.43 \mathrm{~cm}$. Interaction between different cultivation systems and cultivars revealed that 'Fullness' grown under both organic and conventional cultivation systems had high fruit diameter and weight with values of 9.90 to $10.30 \mathrm{~cm}$ and 292.88 to 325.98 g, respectively, while 'Israel' grown under both organic and conventional cultivation systems had high fruit length with values of 13.05 to $13.81 \mathrm{~cm}$. Plants grown under the conventional cultivation system had a higher fruit number per plant than those grown under organic cultivation with a value of 17.18 fruits. 'Wasedaimaru' had the highest number per plant of 21.62 fruits, followed by 'Fullness', 'Black Beauty' and 'Israel'. Interaction between different cultivation systems and cultivars showed that 'Wasedaimaru' grown under the conventional cultivation system had the highest fruit number per plant of 24.25 fruits, followed by the same cultivar grown under the organic cultivation system. Other treatments had a low fruit number per plant of between 12.75 and 15.25 fruits. Plants grown under conventional cultivation systems had a higher yield per plant than those grown under organic cultivation systems with values of 4,573.10 g. The highest yield per plant was 'Wasedaimaru' with a value of 5,646.20 g, followed by 'Fullness'. 'Black Beauty' and 'Israel' had relatively low yields per plant with values of $2,864.00$ to $3,427.00 \mathrm{~g}$ (Table 4).

\section{Discussion}

Results from the soil properties analyses revealed that soil after plant growth under the organic cultivation system had more fertility properties including $\mathrm{N}$, Available $\mathrm{P}, \mathrm{K}, \mathrm{Ca}$ and $\mathrm{Mg}$ than soil after plant growth under the conventional cultivation system 
because cattle manure slowly released nutrients throughout the cultivation period. These findings were supported by Ullah et al. (2008) who reported that organic manure was slow to release adequate nutrients. Under the organic cultivation system, soil (both before and after growth) had higher nitrogen and organic matter than under the conventional cultivation system because before the experiment sunn hemp was plowed in as green manure. At the early bloom stage, nitrogen recovery was the highest. Up to 134 to $147 \mathrm{lb} /$ acre of nitrogen and 3 tons/acre air-dry organic matter can be produced at 60 days of growth, giving $40 \mathrm{~kg}$ seed $/ \mathrm{ha}^{-1}$ (Wang \& McSorley, 2018). Similarly, the United States Department of Agriculture (1999) reported that sunn hemp has been used extensively as green manure because of its ability to produce large amounts of biomass in as little as 60 to 90 days, with the potential to build organic matter levels.

Japanese eggplants grown under the organic cultivation system had lower plant height and width than those grown under the conventional cultivation system because organic cultivation is stressful, largely due to an insufficient supply of nutrients throughout the crop cycle (Ceglie et al., 2016). These results concurred with Chanapan et al. (2016) who determined that cowpea and yard-long bean grown under organic cultivation had lower growth than these crops grown under the conventional cultivation system. The previous study showed that using only organic manure did not increase plant vegetative growth because nutrients were released at a slower rate (Ullah et al., 2008). Crop cultivation under conventional cultivation systems can utilize advantage nutrients faster and better than growth under an organic cultivation system (Benchasri, 2015). Results of this study showed that most Japanese eggplant cultivars grown under the organic cultivation system exhibited good growth characteristics that were not significantly different from those grown under the conventional cultivation system except for 'Wasedaimaru'. Plants grown under the conventional cultivation system had earlier time to $50 \%$ flowering than those grown under the organic cultivation system because plants grown under the conventional cultivation system were supplied with sufficient nutrients from the chemical fertilizers which increased the production of photosynthates (carbohydrates) needed for flower induction (Rehman et al., 2015). This result was supported by Nooprom et al. (2018) who reported that broccoli grown under the conventional cultivation system with chemical fertilizers had earlier time to $50 \%$ flowering and harvest than broccoli grown under the organic cultivation system using cattle manure. Moreover, plants grown under the conventional cultivation system gave a higher yield per plant than those grown under the organic cultivation system. Similar results were recorded by Benchasri \& Simila (2017) and Benchasri \& Pruthikanee (2018) in chili. Although Japanese eggplants grown under the organic cultivation system had lower yield than those grown under the conventional cultivation system, they had higher profitability because organic vegetable crops can command a higher price than those grown under conventional cultivation systems using chemicals with the extra value of 20 to $30 \%$ (Nooprom, 2015).

Each cultivar of Japanese eggplant grown under both organic and conventional systems had different growth characteristics, including plant height and plant width, because plant growth is controlled by genetic makeup and adaptability to soil and climatic conditions (Bilal et al., 2019). 'Fullness' had an earlier time to $50 \%$ flowering than other cultivars due to genetic variations that play an important role in plant flowering (Rehman et al., 2015). Moreover, 'Fullness' had an early time to $50 \%$ harvest because of early fruit setting due to minimum time to $50 \%$ flowering (Shahid et al., 2017). Besides, each cultivar of Japanese eggplant also had different yield characteristics including fruit diameter, fruit length, fruit weight, and fruit number per plant. These characteristics were caused by genetic diversity similar to growth characteristics. 'Wasedaimaru' had the highest yield per plant with a value of $6,848.40 \mathrm{~g}$ because this cultivar had the highest fruit number per plant of 24.25 fruit. Moreover, it also had a high fruit weight.

\section{Conclusion}

The qualitative variables of this study depended entirely on the Japanese eggplant cultivars. 'Wasedaimaru' and 'Fullness' showed potential for growth under the organic cultivation system because they gave high yields of fruit diameter, fruit length, fruit weight, fruit number per plant, and yield per plant, similar to those grown under the conventional cultivation system. These cultivars should be recommended for eggplants farmers in Thailand.

\section{Acknowledgement}

The authors would like to thank the Faculty of Agricultural Technology, Songkla Rajabhat University, Muang, Songkhla, Thailand for support by providing the experimental equipment and access to the field site.

\section{Conflict of interest}

We all the authors hereby declare that there is no conflict of interest among us.

\section{References:}

Abbas MA, Elamin SDM, Elamin EAM (2011) Effects of chicken manure as component of organic production on yield and quality of eggplant (Solanum melongena L.) fruits. Journal of Science and Technology 12: 1-7.

Ali MA, Gençoğlan C, Gençoğlan S (2019) The Effects of organic and inorganic Fertilizer applications on yield and plant vegetative 
growth of Eggplant (Solanum melongena L.). International Journal of Plant and Soil Science 29: 1-9.

Benchasri S (2015) Effects of chemical and organic agricultural systems for okra (Abelmoschus esculentus L. Moench) production in Thailand. Australian Journal of Crop Science 9: 968-975.

Benchasri S, Pruthikanee P (2018) Genetic variability for yield and yield components of Thai chilli (Capsicum spp.) landraces under inorganic and organic agricultural systems. Australian Journal of Crop Science 12: 126-134

Benchasri S, Simla S (2017) Potential of chili varieties under chemical and organic agricultural systems in Thailand. Bulgarian Journal of Agricultural Science 23: 58-70.

Benchasri S, Simla S, Pankaew S (2017) Evaluation of yield components on Capsicum spp. under two production systems. Journal of Advanced Agricultural Technologies 4: 18-22.

Bilal H, Aman F, Ullah I, Awan AA, Ullah S, Khan S, Aamir M, Khan MA, Rome B (2019) Response of chilli varieties to various sources of organic fertilizers. ARPN Journal of Agricultural and Biological Science 13: 15-24.

Campion AL, Oury FX, Heumez E, Rolland B (2020) Conventional versus organic farming systems: dissecting comparisons to improve cereal organic breeding strategies. Organic Agriculture 10: 63-74.

Ceglie FG, Amodio ML, Colelli G (2016) Effect of organic production systems on quality and postharvest performance of horticultural produce. Horticulturae 2: 1-7.

Chanapan D, Benchasri S, Simla S, Siritrakulsak P, Sanputawong S (2016) Comparison on some responds of yardlong bean and cowpea under two production systems. Songklanakarin Journal of Plant Science 3: 1-9.

Clark S (2020) Organic farming and climate change: the need for innovation. Sustainability 12: 1-7.

Das S, Chatterjee A, Pal TK (2020) Organic farming in India: a vision towards ahealthy nation. Food Quality and Safety 4: 69-76.

Decoteau DR (2000) Vegetable Crops. Prentice Hall, New Jersey.

Fajriana H, Farmawati A, Lestari LA (2017) Antioxidant effect of purple eggplant flour (Solanum melongena L.) against oxidative stress in hyperglycaemic rates. Romanian Journal of Diabetes Nutrition and Metabolic Diseases 24: 247-254.

International Federation of Organic Agriculture Movements (2009) Consultation on Review Principles of Organic Agriculture. Die Deutsche Bibliothek, Bonn.
Lima GPP, Vianello F (2011) Review on the main differences between organic and conventional plant-based foods. International Journal of Food Science and Technology 46: 1-13.

Luthria D, Singh AP, Wilson T, Vorsa N, Banuelos GS, Vinyard B (2010) Influence of conventional and organic agricultural practices on the phenolic content in eggplant pulp: plant-to-plant variation. Food Chemistry 121: 406-411.

Maynard A (2016) Special Eggplant Trails 2010-2012. Available at https://th.city/vy0bl, accessed on 22 October 2020.

Niño-Mediana G, Urías-Orona V, Muy-Rangel MD, Heredia JB (2017) Structure and content of phenolic in eggplant (Solanum melongena) - a review. South Africa Journal of Botany 111: 161169.

Nooprom K (2015) Organic vegetable production. Thai Science and Technology Journal 23: 956-965.

Nooprom K, Chumthong A, Mansuriwong P, Thongnui F (2018) Effect of cattle manure and bioextract on growth and yield of broccoli. Thai Science and Technology Journal 25: 628-638.

Orsini F, Maggio A, Rouphale Y, Pascale SD (2016) "Physiological Quality" of organically grown vegetables. Scientia Horticulturae 208: 131-139.

Rehman R, Shahid M, Abbas A, Shireen M, Zakaria, K (2015) Effect of organic and inorganic fertilizers on brinjal cultivars under the agro-climatic conditions of Mansehra. Journal of Biology, Agriculture and Healthcare 5: 14-19.

Shahid U, Ahmad I, Muhammad A, Zainub, B (2017) Effect of organic manure and inorganic fertilizer on the quality of eggplant cultivars. Journal of Biology, Agriculture and Healthcare 7: 107114.

Sriwichai N (2004) Farmers' satisfaction towards Japanese eggplant production farmer contract farming, Mae Hong Son province. (Masters' Minor Thesis). Chiang Mai University, Thailand.

Suja G, Jyothi AN, Byja G (2016) Response of varieties of elephant foot yam (Amorphophallus paeoniifolius) to organic management. Indian Journal of Agricultural Sciences 86: 115-121.

Thailand's Department of Agricultural Extension (2021) Report of Japanese eggplant production in Thailand, 2020. https://th.city/p2jxF, accessed on 09 January 2021.

Ullah MS, Islam MS, Islam MA, Haque T (2008) Effects of organic manures and chemical fertilizers on the yield of brinjal and soil properties. Journal of Bangladesh Agricultural University 6: 271-276. 
United States Department of Agriculture (1999) Sunn Hemp: a https://th.city/kzmw1Y, accessed on 20 October 2020.

cover crop for southern andtropical farming systems.

https://th.city/z7UQ3, accessed on 20 October 2020.

Yu X, Guo L, Jiang G, Song Y, Muminov MA (2018) Advances of organic products over conventional productions with respect

Wang KH, McSorley R (2018) Management of Nematodes and to nutritional quality and food security. Acta Ecologica Sinica

Soil Fertility with Sunn Hemp Cover Crop. 38: 53-60. 